\title{
Effect of the Exposure to Workplace Bullying on Turnover Intention and The Mediating Role of Job Satisfaction, Work Engagement, and Burnout
}

\author{
Ernesto Rosario-Hernández ${ }^{1}$, Lillian V. Rovira Millán², Jaime Vélez Ramos, María Cruz, Elba \\ Vélez, Gadier Torres, Giovanni Alomar, Jason Caldera, Josue Vera, Miriam Santiago, Yoaris Arroyo \\ \& Ivelize Sánchez, Naily Rodríguez ${ }^{3}$
}

Recibido: 06/06/2018 Aceptado: 25/09/2018

DOI: $10.21772 /$ ripo.v37n1a03

\begin{abstract}
Statement of the Problem: One of the great challenges for organizations today is the retention of valuable human resources because this is essential to them for being globally competitive and one of the factors that can exacerbate turnover intention is the exposure to workplace bullying. Purpose: The purpose of the present investigation was to examine the effect of exposure to psychological harassment on the intention to give up employment and how job satisfaction, work engagement and burnout mediate the relationship between exposure to workplace bullying and turnover intention. Method: A cross-sectional/correlational design was used and a total of 1,046 employees were surveyed. We used the partial least squares structural equation modeling (PLS-SEM) to examine the hypotheses of the study. Results: The results suggest that exposure to workplace bullying has a direct effect on the turnover intention. In addition, it was found that job satisfaction, work engagement and burnout mediated the relationship between exposure to workplace bullying and turnover intention. Discussion: Exposure to workplace bullying can make victims consider giving up their jobs as a form of coping. Employees' turnover has an extremely high organizational cost in terms of recruiting and training new staff.
\end{abstract}

Keywords: Workplace Bullying, Turnover Intention, Work Engagement, Burnout

\section{Efectos de la exposición al acoso psicológico en la intención de renunciar al empleo y el papel mediador de la satisfacción laboral, el engagement y el síndrome de quemarse por el trabajo.}

\begin{abstract}
Resumen
Planteamiento del problema: Uno de los grandes retos para las organizaciones hoy en día es la retención de recursos humanos valiosos porque de ello depende que las mismas se mantengan competitivas globalmente y uno de los factores que puede exacerbar la intención a renunciar es la exposición al acoso psicológico. Propósito: El propósito de la presente investigación fue examinar el efecto de la exposición al acoso psicológico en la intención a renunciar al empleo y cómo la satisfacción laboral, el engagement con el trabajo y el burnout median la relación entre el acoso psicológico y la intención a renunciar. Método: Se utilizó un diseño transversalcorrelacional y se encuestó un total de 1,046 empleados. Se utilizó el modelo de ecuaciones estructurales basado en residuales (PLSSEM) para examinar las hipótesis del estudio. Resultados: Los resultados sugieren que la exposición al acoso psicológico tiene un efecto directo en la intención de renunciar. Además, se encontró que la satisfacción laboral, el engagement con el trabajo y el burnout mediaron la relación entre la exposición al acoso psicológico y la intención de renunciar al empleo. Discusión: La exposición al acoso psicológico puede hacer que las víctimas consideren renunciar a sus empleos como una forma de afrontamiento. Las renuncias al empleo por parte de los empleados tienen un costo organizacional sumamente alto en cuanto al reclutamiento y adiestramiento del nuevo personal.
\end{abstract}

Palabras Claves: Acoso Psicológico, Intención de Renunciar, Engagement con el Trabajo, síndrome de quemarse por el trabajo

\footnotetext{
1 Ph.D. en Psicología Industrial-Organizacional. Ponce Health Sciences University. School of Behavioral \& Brain Sciences. Ponce, Puerto Rico. E-mail: erosario@psm.edu

2 Ph.D. en Psicología Clínica. Universidad de Puerto Rico en Cayey. Departamento de Ciencias Sociales. Cayey, Puerto Rico. E-mail: lillian.rovira@ upr.edu

3 M.S. en Psicología Industrial-Organizacional. Estudiantes doctorales en psicología industrial-organizacional. Pontificia Universidad Católica de Puerto Rico. Colegio de Estudios Graduados. Departamento de Psicología. Ponce, Puerto Rico

Note: part of this paper was presented at the XV Caribbean Congress of Psychology, April 7 - 8, 2018 at the Universidad Tecnológica de Santiago (UTESA), Puerto Plata, Dominican Republic.

Cómo citar este artículo: Rosario-Hernández, E.; Rovira Millán, L. V.; Et al. (2018). Effect of the Exposure to Workplace Bullying on Turnover Intention and The Mediating Role of Job Satisfaction, Work Engagement, and Burnout. Revista Interamericana de Psicología Ocupacional, 37(1), 26-51. DOI: 10.21772/ripo.v37n1a03
} 


\section{Introduction}

The most significant challenge of organizations in a fast paced business world that want to compete globally is the retention of valuable human resource because in order to be able to compete it is necessary to attract and retain employees with needed or critical skills (Sinha \& Sinha, 2012; van Dyk, 2016). One factor that may exacerbate turnover intention of valuable employees is the exposure to workplace bullying (Rodwell, Brunetto, Demir, Shacklock, \& FarrWharton, 2014; van Dyk, 2016).

Workplace bullying is becoming a core issue for the organizations nowadays (Rasool, Arzu, Hassan, Rafi, \& Kashif, 2013). Research's results, including Puerto Rico, suggest that workplace bullying has been implicated in impairing psychological health such as depression, anxiety, and symptomatology that resembles posttraumatic stress disorder (e.g., Rosado Vázquez, 2005; Rosario-Hernández \& Rovira Millán, 2011; Rosario-Hernández, Rovira Millán, Pons Madera, Rodríguez, \& Cordero, 2009; Rosario-Hernández et al., 2013). Also, research's results suggest that physiological outcomes impacted employees exposed to workplace bullying such as sleep disorders, physical symptom complaints, and cardiovascular diseases (e.g., Rosario-Hernández et al., 2013; RosarioHernández et al., 2014; Rosario-Hernández et al., 2018).

According to Bernstein and Trimm (2016), such severe individual implications, in turn, have serious organizational outcomes as employees exposed to workplace bullying experience reduced job satisfaction and increased turnover intention, which is a form of exclusion from work. Thus, exposure to workplace bullying may bring the risk of exclusion from work (Berthelsen et al., 2011; Leymann, 1996), which may take different forms such as any illegitimate distance between an employee and the work he was hired to do. Moreover, Piñel y Zabala (2001) points out that the ultimate goal of workplace bullying behaviors is to eliminate its target from the organization since this satisfy the bullies' needs to destroy its victim to canalize his/her impulses and psychopathic tendencies. Thereafter, the victim of such negative acts may choose to quit voluntarily because of the adverse nature of the working conditions in which bullying occurs (Berthelsen et al., 2011). Thus, previous research suggest that exposure to workplace bullying is linked to turnover intention (e.g., Bahjat, Aljawazneh, Moh, Smadi, \& Ziad, 2017; Coetzee \& Oosthuizen, 2017; Coetzee \& van Dyk, 2017; Rasool et al., 2013).

Although the association between exposure to workplace bullying and high turnover intention is clear from the research literature, there is a lack of understanding about the mechanism that may play a critical role in this relationship. Some studies have considered as part of this mechanism job satisfaction (e.g., Nwobia \& Aljohani, 2017) and work engagement (e.g., Coetzee \& van Dyk, 2017), but none of them have considered examine the mediating effect of these variables together on the relationship between exposure to workplace bullying and turnover intention. Moreover, burnout has not been studied either alone or in conjunction with job satisfaction and work engagement as part of this mechanism.

Therefore, the purpose of this crosssectional study is to examine the direct effect of workplace bullying on turnover intention in a Puerto Rican sample of employees. Also, we want to examine the mediating effects of job satisfaction, work engagement, and burnout on the relationship between exposure to workplace bullying and turnover intention.

\section{Theoretical framework}

As a theoretical framework, we used the Stress-Strain-Turnover Process proposed by Fila, Eatough, and Griffeth (2016; see figure 1), in which are integrated four models: (1) General 
Stressor-Strain Framework (Kahn \& Byosiere, 1992), (2) Turnover Theory (Hom \& Griffeth, 1995), (3) Cognitive Theory of Stress (Lazarus \& Folkman, 1984), and (4) Work DemandsControl-Support (Karasek \& Theorell, 1990). This integrated Stress-Strain-Turnover Process Model proposes that the individual appraises work demands and depending of the control and support that he/she perceives has on work demands is the likelihood of the appearance of strain. If the individual thinks he/she has control of the stressor and the support at work to manage it, this buffer that enables the individual to cope (Van der Doef \& Maes, 1999). However, if the individual thinks that he/she does not have the control and proper support at work, strain is very likely to appear. In this case, the model proposes that strain leads to changes in attitudes and behaviors, specifically, the enactment of behavioral coping mechanisms (Kahn \& Byosiere, 1992). Ajzen and Fishbein (1980) argue that these behaviors are generally reasoned before enacted. The underlying idea is that strain drives individuals to seek alternative employment opportunities with the goal of reducing strain levels (Brotheridge \& Grandey, 2002). Thus, psychological strain is closely tied to affective states; turnover intention is thought to be an attitude (Hom \& Griffeth, 1995). Of course and according to Fila et al. (2016), not all individuals who experience occupational stress experience strain, and not all people who experience strain will desire to leave the organization as a result. Similarly, not everyone who desires to leave the organization will actually do so. Fila et al. consider that an individual perception or appraisal of the stressor is a general approach they suggest could capture many potentially influential individual-difference factors. Thus, the cognitive appraisal theory of stress (Lazarus \& Folkman, 1984) contributes to the Stressor-Strain-Turnover Process Model by incorporating cognitive appraisal into the process. Furthermore, the process of appraisal may be triggered by specific event; in the current study is the exposure to workplace bullying, which has been considered as a hindering stressor in other studies (e.g., Rosario-Hernández et al., 2014). A hindering stressor is one that represents a threat to one's well-being and represents a harm or loss that is perceived as a damage already sustained (Fila et al., 2016). Therefore, we propose the mechanism that exposure to workplace bullying will result in negative attitudes and strain in the form of job dissatisfaction, low work engagement and increasing levels of burnout, which will mediate the relationship between the exposure to workplace bullying and turnover intention (see figure 2).

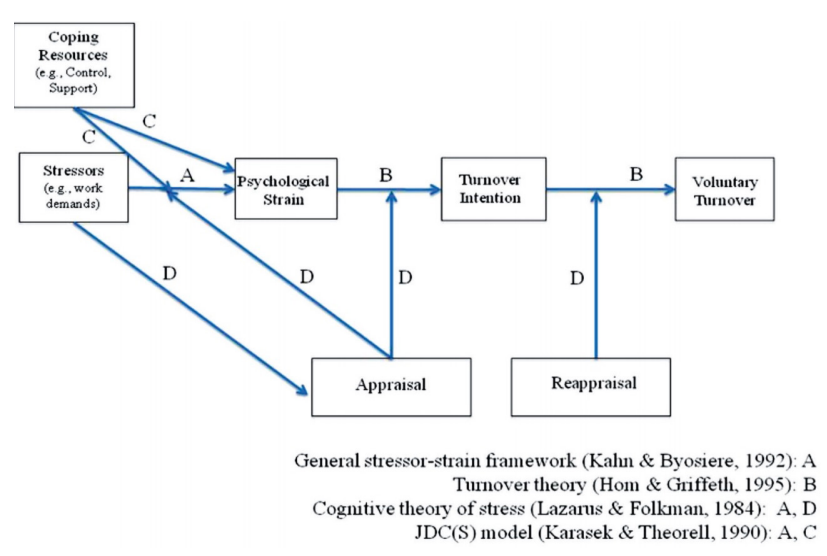

Figure 1: Stress-Strain-Turnover Process model (Fila, Eatough, \& Griffeth, 2016). Reproduced with Permission.

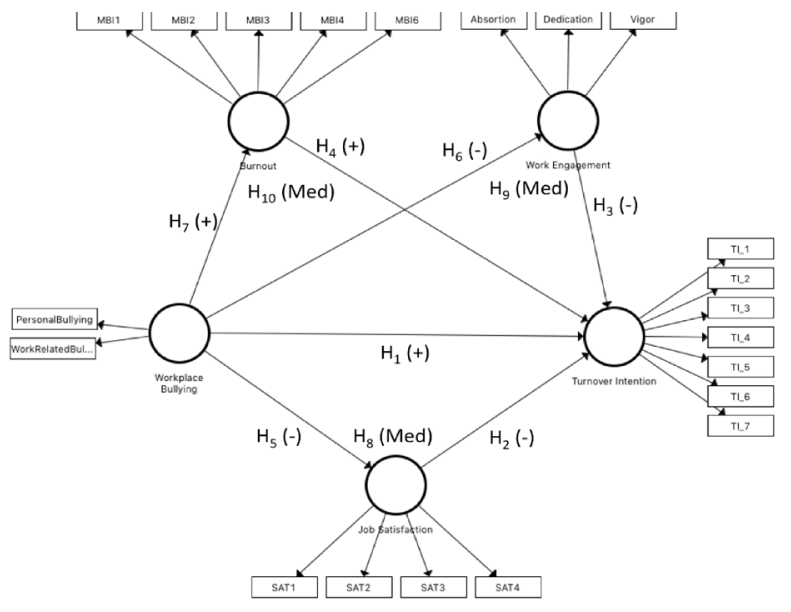

Figure 2: Research model proposed. 


\section{Workplace bullying}

Workplace bullying is the process in which an employee is subjected to frequent negative acts (e.g., at least once a week) for a relatively long period of time (e.g., six months) by peers or superiors, against which defense or retaliation is hindered by the recognition of a formal or informal power imbalance (Einarsen, Hoel, Zapf, $\&$ Cooper, 2011). These negative acts may be work related as well as person related, and they comprise direct acts, such as verbal aggression, obstruction of work tasks and physical violence, as well as indirect behaviors, such as social exclusion or veiled job sabotage (Barlett \& Barlett, 2011). The Workplace Bullying Institute (WBI; 2014) suggest that $27 \%$ of American has been exposed to workplace bullying. Meanwhile, in Puerto Rico the Workplace Bullying Alliance (WBA; 2015) conducted a national survey using the same questionnaire used by WBI and found that $51.8 \%$ of Puerto Rican workers was exposed to negative acts related to workplace bullying. As Glambek, Matthiesen, Hetland, and Einarsen (2014) have stated, exposure to workplace bullying can be described as a significant challenge for employees as well as organizations because of its negative consequences on both. According to Leymann (1990, 1996), if workplace bullying is not handled properly by the employer, exclusion from work in one form or another is typically the final stage of the bullying process, leading the target to further stigmatization and victimization, and difficulty in finding and maintaining work later on. Therefore, potential exclusion from work due to exposure to workplace bullying is turnover intention.

\section{Turnover intention}

Turnover intention is defined as a premeditated and intentional willfulness to leave the organization (Tett \& Meyer, 1993). The employee has the deliberate goal or determination to end its current employment (De Tienne, Agle,
Phillips, \& Ingerson, 2012). According to Tett and Meyer, employees' turnover intention is a central mental precursor of their definite turnover action and the final stage before they display action to exit the organization. Therefore, turnover intention is a workplace phenomenon that must be restrained as much as possible for it involves impairments (Coetzee \& Oosthuizen, 2017). Within the scope of human resources management, employee turnover intention is a critical affair due to its organizational cost (Abbasi \& Hollman, 2008). Thus, an important consequence of turnover intention is the high cost for companies that involves recruiting and training new employees (Wöck \& Heymann, 2012).

\section{Workplace bullying, job satisfaction, work engagement and burnout on turnover intention}

Exposure to workplace bullying is proposed to have implications for job-related outcomes to extend that victimized employees feel that the organization is partly responsible for the occurrence and frequency of such negative acts (Nielsen \& Einarsen, 2012) and an important job-related outcome is turnover intention. For example, Coetzee and Oosthuizen (2017) conducted a cross-sectional study with a sample of 373 employees from various and diverse organizations and found that workplace bullying was related to turnover intention $(\mathrm{r}=.40, \mathrm{p}<.05)$. In another study, Coetzee and van Dyk (2017) found that work-related bullying, personal-related bullying, and physical intimidation correlated significantly to turnover intention $(\mathrm{r}=.45, .34$, \& .29, $\mathrm{p}<.05$, respectively). Meanwhile, Van Schalkwyk, Els, and Rothmann (2011) found a positive relationship between exposure to workplace bullying strategies from supervisors and colleagues and turnover intention $(\mathrm{r}=.28 \&$ $.21, \mathrm{p}<.01$, respectively) in a convenience sample of 13, 911 employees. Razzaghian and Ghani (2014) found that workplace bullying accounts for $20.4 \%$ variation on turnover intention in a 
sample of 207 faculty members of different private universities. Moreover, there are some studies in which examined the long-term effects of exposure to workplace bullying on turnover intention; for example, Glambek et al. (2014) conducted a longitudinal study in which they examined if exposure to workplace bullying has an effect on turnover intention and if this effect persists for a long period of time. They found that the effects of exposure to workplace bullying on turnover intention held as indicative of longevity of its negative effects. In another longitudinal study, Clausen et al. (2016) did not find an association between exposure to workplace bullying and turnover intention neither at base line nor after one year of follow-up. However, after they stratified by occupation, exposure to workplace bullying predicted risk of turnover, among office workers but not among human service and sales workers and among manual workers. We propose the following hypothesis:

$\mathrm{H}_{1}$ : Exposure to workplace bullying is positively related to turnover intention.

Job satisfaction is probably the oldest and most investigated variable in organizational behavior research. Judge, Hulin, and Dalal (2012) define job satisfaction as an internal evaluation of the favorability of one's job. Job satisfaction refers to the employee's affective response to a job, based on the employee's comparison between his or her desired outcomes and the actual outcomes (Egan, Yang, \& Bartlett, 2004). There are some studies results that suggest that job dissatisfaction is positively related to turnover intention (Irvine \& Evans, 1995; Mobley, 1982; Trevor, 2001). Thus, Abu Raddaha et al. (2012) conducted a cross-sectional study with a convenient sample of 180 critical care nurses and reported that 59\% of the that they were "Likely" or "Very Likely" to leave their current job. They also found that job dissatisfaction predicted turnover intention. Meawhile, Xie, Liu, and Deng (2015) found a negative relationship between job satisfaction and turnover intention $(\beta=-.668, \mathrm{p}<.001)$ in a convenient sample of 266 graduate students in China. Therefore, we propose the following hypothesis:

$\mathrm{H}_{2}$ : Job satisfaction is negatively related to turnover intention.

Work engagement is defined as a positive, fulfilling, work-related state of mind that is characterized by vigor, dedication, and absortion (Schaufeli, Salanova, González-Romá, \& Bakker, 2002). Rather than a momentary, specific emotional state, engagement refers to a mood, is a more persistent and pervasive affective-cognitive state that is not focused on any particular object, event, individual, or behavior (Schaufeli \& Salanova, 2007). Employees who are engaged in their work find it energizing, they experience a sense of pride in what they do, time at work passes quickly and they have a sense of personal fulfillment (Biggs, Brough, \& Barbour 2013; Ryan \& Deci 2001; Saks 2006). Schaufeli and Bakker (2004) describe of an upward positive spiral where work engagement and self-efficacy lead to improved performance in both work and family domains is one of synergy and demonstrates some similarity with May, Gilson, and Harter's (2004) engagement of the human spirit at work. Similarly, Carlson, Kacmar, Wayne, and Grzywacz (2006) suggested that the feeling of mastery gained through personal accomplishment contributed benefits across domains, thus empowering people to rise to challenges. According to Laschinger and Finegan (2005), empowerment of workers provides the means by which organizations can address shortages of skilled workers, by attracting highly qualified applicants and reducing absenteeism and turnover. This echoes a common theme within organizational research that engaged workers are less likely to seek alternative employment (Maslach, Schaufeli, \& Leiter 2001; Schaufeli \& Bakker, 2004; Timms \& Brough 2013). There are some studies that have found a negative association between work engagement and turnover intention; for example, Coetzee and van Dyk (2017) found significant correlations 
between different strategies of workplace bullying and work engagement and its dimensions that ranged from $r=-.40$ to $r=-.53$ in a convenient sample of 373 employees, suggesting that work engagement might buffer turnover intention. We propose the following hypothesis:

$\mathrm{H}_{3}$ : Work engagement is negatively related to turnover intention.

Past research has demonstrated that exposure to workplace bullying result in deteriorated mental and physical health, higher level of job burnout, increased turnover intentions, and reduced job satisfaction and organizational commitment of the victims (e.g., Bowling \& Beehr, 2006; Laschinger, Grau, Finegan, \& Wilk, 2010; Nielsen \& Einarsen, 2012). In a meta-analysis conducted by Nielsen and Einarsen (2012), it was found an average bullying/burnout correlation of $\mathrm{r}=.27$ across 10 cross-sectional studies in the general management field. Other researchers have also found significant relationships between bullying and burnout in cross-sectional studies (e.g., Meliá \& Becerril, 2007; Sá \& Flemming, 2008). In a study conducted by Yeun (2015), it was found that burnout, specifically the emotional exhaustion, was a better predictor of turnover intention that exposure to workplace bullying in a sample of 270 nurses in Korea. We propose the following hypothesis:

$\mathrm{H}_{4}$ : Burnout is positively related to turnover intention.

\section{Workplace bullying on job satisfaction, work engagement, and burnout}

As Muchinsky and Culbertson (2016) resume it, job satisfaction reflects the degree of pleasure an employee derives from his or her job. According to Nielsen \& Einarsen (2012), the inability to cope with unwanted and unfair treatment at work, such as exposure to workplace bullying, can lead to a cognitive dissonance that results in prolonged activation and feelings of discomfort. Being in such a long-lasting uncomfortable state subsequently develop into job dissatisfaction. For example, RodríguezMuñoz, Baillien, De Witte, Moreno- Jiménez, \& Pastor (2009) found in a longitudinal study that after two years of exposure to workplace bullying, it predicted negatively job satisfaction. They concluded that exposure to workplace bullying wears out its targets and consequently leads to a decrease in job-related well-being and this appears as a strain (e.g., job dissatisfaction) when individual is exposed to certain stressor workplace bullying for a longer time. Thus, we propose the following hypothesis:

$\mathrm{H}_{5}$ : Exposure to workplace bullying is negatively related to job satisfaction.

Organizations would be well advised to address workplace bullying because it causes employee absenteeism, turnover, and a substantial loss of productivity, profits, and work engagement (Hauge, Skogstad, \& Einarsen, 2010; Hoel, Sheehan, Cooper, \& Einarsen, 2011; Leymann, 1990; Nielsen \& Einarsen, 2012). In fact, the financial costs for an organization for each case of workplace bullying are estimated to be in the tens of thousands of dollars annually, collectively costing billions of dollars at an organizations national level (Hoel et al., 2011). Because of the aforementioned psychological costs to victims of the bullying and financial costs to organizations, it is important to understand the process through which workplace bullying effects employees' well-being, and subsequently, engagement in their work. Research (Rodríguez-Muñoz et al., 2009) already shows that negative relationships exists between exposures to workplace bullying and work engagement, concluding that high exposure to bullying may rather proportionally and directly result in a decrease in work engagement. Thus, we propose the following hypothesis:

$\mathrm{H}_{6}$ : Exposure to workplace bullying is negatively related to work engagement.

Besides the effects of the exposure to 
workplace bullying of job-related outcomes, such as job dissatisfaction and work engagement, there is also evidence from research that exposure to workplace bullying has an effect on the psychological well-being of employees. For example, in the Puerto Rican work context, there are studies that have found that exposure to workplace bullying has been associated to depression, anxiety, posttraumatic stress symptoms, somatization, cardiovascular disease, and sleeping difficulties (Rosado Vázquez, 2005; Rosario-Hernández \& Rovira Millán, 2011; Rosario-Hernández et al., 2013; Rosario-Hernández et al., 2014; RosarioHernández et al., in press). In addition to these acute health reactions, it has been claimed the exposure to workplace bullying is also associated with more delayed reactions such as burnout (Einarsen, Matthiesen, \& Skogstad, 1998). Burnout is defined as a state of physical and emotional exhaustion, depersonalization, and reduced efficacy (Demerouti, Bakker, Vardakou, \& Kantas, 2003; Maslach, Schaufeli, $\&$ Leiter, 2001). Though burnout consists of three components emotional exhaustion, cynicism and personal efficacy; however, emotional exhaustion is considered the core element of burnout (Leiter \& Maslach, 2004; Maslach \& Leiter, 1997). Burnout is a well-documented psychological response to chronic job stressors (Maslach, 2004). There are evidence that support the notion that exposure to workplace bullying result in burnout, which causes significant depletion of energy resources, thereby leaving no or fewer resources to, for example, perform work-family roles (Raja, Javed, \& Abbas, 2017). Hence, individuals lose their energy-related resources while coping with stressors such as exposure to workplace bullying. Afterward, this resource loss in mental and physical energy causes further resources loss and triggers exhaustion and burnout (Hobfoll \& Shirom. 2001). Furthermore, Nielsen and Einarsen (2012) conducted a meta-analysis using 137 cross-sectional studies and found an $\mathrm{r}=.27$ significant average correlation between exposure to workplace bullying and burnout. Therefore, we propose the following hypothesis:

$\mathrm{H}_{7}$ : Exposure to workplace bullying is positively related to burnout.

\section{The mediating effect of job satisfaction, work engagement, and burnout}

The current study proposes that job satisfaction, work engagement and burnout serve as mechanisms that might explain the effect of exposure to workplace bullying on turnover intention. This proposition is due to job dissatisfaction and burnout are regarded as forms of psychological strain induced by stress because they are inherent indicators of a lack of psychological well-being at work (Häusser et al., 2010; Kahn \& Byosiere, 1992; Lee \& Ashforth, 1996) and are established antecedent of turnover (Griffeth \& Hom, 2001; Hom \& Griffeth, 1995; Todd \& Deery-Scmitt, 1996; Wright \& Cropanzo, 1998). On the other hand, work engagement is a relatively new construct when compared to job satisfaction and burnout, and it is considered to be in the opposite continuum of burnout (e.g., González-Romá, Schaufeli, Bakker, \& Lloret, 2006). Therefore, some literatures consider work engagement as a positive, fulfilling and affective motivational state of work-related well-being (Bakker, Schaufeli, Leiter, \& Taris, 2008; Warr \& Inceoglu, 2012). The motivational drive leads to the expending of energy even if well-being is being threatened (Warr \& Inceoglu, 2012).

In terms of the mediating effect of job satisfaction, Fila (2014) conducted a study examining the mediating role of job satisfaction on the relation between stressful work and turnover intention and found that job satisfaction partially mediated this relationship. Thus, appears that exposure to workplace bullying might have an indirect effect on turnover intention through job satisfaction. In this way, we propose the following hypothesis:

$\mathrm{H}_{8}$ : Job satisfaction negatively mediates the relation between exposure to workplace bullying and turnover intention. 
In regard to work engagement, Storm and Rothman (2003) indicate that work engagement functions as a personal coping resource which could explain the buffering effect of work engagement on the relation between exposure to workplace bullying and turnover intention. Some studies' results (e.g., Coetzee \& van Dyk, 2017) tend to support this notion of the mediation effect of work engagement in which it was found a significant indirect effect $\quad(b=.13, p<.01)$. Moreover, Coetzee and van Dyk found more strong indirect effects of work engagement when using its vigor and dedication dimensions on the relation between exposure to workplace bullying and turnover intention $(b=-.24$ and $b=-.30, p<$ .01 , respectively) suggesting that exposure to workplace bullying lower employees' sense of vigor and dedication, which may in turn result in higher turnover intention. Thus, we propose the following hypothesis:

$\mathrm{H}_{9}$ : Work engagement negatively mediates the relation between exposure to workplace bullying and turnover intention.

In addition to its direct effect, we propose that burnout serves as the pathway through which exposure to workplace bullying affects organizational outcomes such as turnover intention. We anticipate that exposure to workplace bullying would result in high levels of burnout due to results from previous research (e.g., Livne \& Goussinsky, 2017; Varhama \& Björkqvist, 2004). There is literature suggesting that unusually high or chronic stressors may predispose individuals to a downward spiral whereby burnout ensues due to continuous resource loss (e.g., Demerouti, Bakker, \& Bulters, 2004; Hobfoll, 1989). Our argument about the mediating role of burnout in the relationship of exposure to workplace bullying with turnover intention specifies burnout as antecedent of turnover intention is supported by the results of
Fila (2014), who found that burnout, specifically emotional exhaustion, mediated this relationship. The impact of burnout on turnover intention is well documented (e.g., Cherniss, 1980; Maslach, 1982). Burnout has been identified as an outcome of physical and psychological job demands (e.g., Bakker, Demerouti, \& Verbeke, 2004; Jourdain \& Chênevert, 2010; Zapf, Seifert, Schmutte, Mertini, \& Holz, 2001). In a similar vein, exposure to workplace bullying exerts physical and psychological demands on individuals (e.g., Rosado, 2005; Rosario-Hernández, 2011; RosarioHernández et al., 2013; Rosario-Hernández et al., 2018), and thus exposure to excessive workplace bullying can result in individuals feeling burnedout. Accordingly, a study by Happell, Martin, and Pinikahana (2003) among psychiatric nurses revealed that burnout positively correlated with the intention of employees to leave their jobs. From the foregoing, it follows that exposure to workplace bullying could be indirectly related to turnover intention via burnout. Therefore, we propose the following hypothesis:

$\mathrm{H}_{10}$ : Burnout positively mediates the relation between exposure to workplace bullying and turnover intention.

\section{Method}

\section{Participants}

A convenience sample of 1,046 workers participated in this cross-sectional study. Participants in the study were enrolled from different private and public organizations in Puerto Rico. As presented on table 1, the sample of the study was composed of 59.4\% (621) females, age mean was 37.73 , while education mean was 16.05 , which it is equivalent to a bachelor' degree. In terms of tenure, $73.9 \%$ (773) had a permanent one, and $65.6 \%$ (686) of the research participants worked for a private organization. 
Table 1. Socio-demographic information about the sample

\begin{tabular}{llllll}
\hline Variable & $\mathrm{n}$ & $\%$ & Variable & $\mathrm{n}$ & $\%$ \\
\hline Gender & & & Type of Organization & & \\
Male & 424 & 40.5 & Public-State & 281 & 26.9 \\
Female & 621 & 59.4 & Public-Federal & 54 & 5.2 \\
Marital Status & & & Private & 686 & 65.6 \\
Single & 358 & 34.2 & Intention to Leave & & \\
Married & 443 & 42.4 & Not at All Likely & 485 & 46.4 \\
Widowed & 14 & 1.3 & Unlikely & 290 & 27.7 \\
Divorced & 113 & 10.8 & Somewhat Likely & 184 & 17.6 \\
Living Together & 111 & 10.6 & Very Likely & 75 & 7.2 \\
Position Type & & & & & \\
Management & 197 & 18.8 & & & Mean \\
Non-Management & 796 & 76.1 & Age & 37.73 & 11.08 \\
Employment Type & & & Education & 16.05 & 2.30 \\
Permanent & 773 & 73.9 & Time Working & 8.75 & 8.33 \\
Temporary & 233 & 22.3 & & & \\
\hline
\end{tabular}

Note: $\mathrm{n}=1,046 ; \mathrm{SD}=$ Standard Deviation.

\section{Materials}

Background questionnaire. We created a background questionnaire to gather information about the research participants. In this background questionnaire we asked the participants to provide information about their gender, age, tenure, marital status, among others, to enable us to described the subjects of the study.

Workplace bullying. To measure exposure to workplace bullying, we used the Negative Act Questionnaire (NAQ) developed by Einarsen, Raknes, \& Matthiesen (1994) and translated into Spanish by Moreno Jiménez, Rodríguez Muñoz, Martínez Gamarra \& Gálvez Herrer (2007). A reduced 14 items version of the NAQ was used to assess workplace bullying. This reduced version of the NAQ has only two subscales, which are personal bullying and work-related bullying. This scale reflects typical bullying behaviors, and the participants should respond to what degree they have suffered such behaviors during the last six months, on a 5-point Likert rating scale, ranging from $\underline{1}$ (never) to $\underline{5}$ (daily). After responding to these items, a definition of bullying is presented and participants are requested to indicate whether they consider themselves victims of bullying according to the definition. The scale has shown good reliability and validity in previous studies (Moreno Jiménez et al., 2007; Rosario-Hernández et al., 2018). An item example is: "Being ordered to do work below your level of competence."

Turnover intention. We used the Turnover Intention Scale developed by Rosario-Hernández and Rovira Millán (2018). This is a seven-item instrument in a Likert-agreement response format ranging from $\underline{1}$ (Totally Disagree) to $\underline{6}$ (Totally Agree), which pretend to measures employee's turnover intention. An item example is: "If a good job opportunity appears, I would not hesitate to accepted it." Cronbach' alpha was reported as $\alpha$ $=.91$ and in terms of its validity, factor analysis results suggest an internal structure of onedimension. 
Job satisfaction. We used the Job Satisfaction Scale developed by RosarioHernández and Rovira Millán (2018). This is a four-item instrument in a Likert-agreement response format ranging from $\underline{1}$ (Totally Disagree) to $\underline{6}$ (Totally Agree), which pretend to measures employee's job satisfaction in general. An item example is: "I enjoy the work I do." Cronbach' alpha was reported as $\alpha=.77$ and in terms of its validity, factor analysis results suggest an internal structure of one-dimension.

Work engagement. We used the Utreach Work Engagament Scale (UWES; Schaufeli et al., 2002). The UWES is comprised of 17 items measured on a seven-point Likert scale anchored by the response options $\underline{0}=$ never and $\underline{6}=$ always. Six items comprised the vigor subscale (e.g., "At my work, I feel busting with energy"). Dedication was measured with five items (e.g., "I find the work that I do full of meaning and purpose"). Finally, the remaining six items comprised the absorption subscale (e.g., "Time flies when I'm working"). Reliability of the subscales and the complete scale has been reported to fluctuate within .82 to .93 (Schaufeli \& Bakker, 2003). Rodríguez Montalbán, Martínez Lugo, and Andújar Rojas (2011) examined psychometric properties and internal structural of the UWES with a sample of Puerto Rican employees and they found that reliability of the scale and its sub-scale fluctuated within .81 to .93 using Cronbach's alpha.

Burnout. We used the emotional exhaustion subscale items from the Maslach Burnout Inventory - General Scale (MBI-GS; Maslach, Jackson, \& Leiter, 1996). Participants used a 7-point frequency scale (ranging from $\underline{0}$-never to $\underline{6}$-daily) to indicate the extent to which they experienced each item (e.g., "I feel emotionally drained from my work."). Cronbach's alpha for the Emotional Exhaustion was reported as $\alpha=.94$. The MBI-GS has two other subscales, which are Cynicism and Professional Efficacy but were not included in the statistical analyses of the current study.

\section{Procedure}

The research proposal was submitted to the Institutional Review Board (IRB) of the Ponce Health Sciences University and it was approved on February 10, 2016 with the protocol number 160208-ER. Participants were contacted from different organizations and were invited to participate in the study. All those who agreed to participate in the study were explained the purpose of the research. They were given the consent form, background data sheet and the study questionnaires. The questionnaires were administered individually as well as in groups by the researchers at the different organizations contacted.

\section{Data analysis}

For data analysis, partial least squares structural equation modeling (PLS-SEM) was used following the two step procedure suggested by Hair, Hult, Ringle, and Sarstedt (2017). First, confirmatory factor analysis aimed to assess the measuring model; and secondly, evaluation of the structural model. It is important to mention the two reasons for its use in the present study, as Chin (2010) points out, that PLS-SEM has a soft distributional assumption and given that the Kolmogorok-Smirnov and Shapiro-Wilks tests were significant suggesting that scores were not distributed normally. Also, the high model complexity of the current study justifies the use of PLS-SEM because the model tested has multiple mediators.

Little, Cunningham, Shahar, and Widaman (2002) recommend the use of parcels in testing structural equation modeling because result in more reliable measurement models. We, therefore, conducted our SEM analysis on a partial disaggregation model (Bagozzi \& Edwards, 1998) by creating parcels of items as also recommended by Hall, Snell and Foust (1999). We created parcels of items for the variables Turnover 
Intention, Burnout, Job Satisfaction, which were included in the model as latent factors with seven, five, and four indicators, respectively. Meanwhile, Exposure to Workplace Bullying and Work Engagement were included as latent factors with the abovementioned subscales as the indicators.

\section{Results}

The research model of fig. 1 was analyzed using Smart-PLS 3.2.4, a PLS structural equationmodeling tool (Ringle, Wende, \& Becker, 2015). It assesses the psychometric properties of the measurement model, and estimates the parameters of the structural model. This tool enables the simultaneous analysis of up to 200 indicator variables, allowing the examination of multiple mediator variables simultaneously among latent predictor variables indicators.

\section{The measurement model}

The data indicates that the measures are robust in terms of their internal consistency reliability as indexed by Cronbach's alpha and composite reliability. All the Cronbach's alphas and the composite reliabilities of the different measures range from .79 to .97 , which exceed the recommended threshold value of .70 (Hair et al., 2017). In addition, consistent with the guidelines of Fornell and Larcker (1981), the average variance extracted (AVE) for each measure exceeds .50, which is an indication of the convergent validity of the measures. Moreover, the elements in the matrix diagonals, representing the square roots of the AVE, are greater in all cases than the offdiagonal elements in their corresponding row and column, supporting the discriminant validity of the scales (see table 2).

Table 2. Correlation matrix between latent constructs, Cronbach's alpha, composite reliability (CR) and the average variance extracted (AVE).

\begin{tabular}{|c|c|c|c|c|c|c|c|c|c|}
\hline & Measures & $\begin{array}{l}\text { Cronbach's } \\
\text { Alpha }\end{array}$ & $\mathrm{CR}$ & AVE & 1 & 2 & 3 & 4 & 5 \\
\hline 1. & $\begin{array}{l}\text { Workplace } \\
\text { Bullying }\end{array}$ & .95 & .97 & .95 & $(.98)$ & & & & \\
\hline 2. & Job Satisfaction & .79 & .88 & .70 & $-.31 * *$ & $(.84)$ & & & \\
\hline 3. & $\begin{array}{l}\text { Work } \\
\text { Engagement }\end{array}$ & .93 & .96 & .88 & $-.27^{* *}$ & $.36^{* *}$ & $(.94)$ & & \\
\hline 4. & Burnout & .92 & .94 & .75 & $.40 * *$ & $-.44 * *$ & $-.25 * *$ & $(.87)$ & \\
\hline 5. & $\begin{array}{l}\text { Turnover } \\
\text { Intention }\end{array}$ & .91 & .93 & .64 & $.36^{* *}$ & $.48 * *$ & $-.34 * *$ & $.48 * *$ & $(.80)$ \\
\hline
\end{tabular}

Note: $\mathrm{n}=1,046 ;{ }^{*} \mathrm{p}<.05,{ }^{*} \mathrm{p}<.01 ;$ the elements in the matrix diagonals within parenthesis represent the square roots of the AVE.

Another approach to examine discriminant validity of the indicators are the cross-loadings; specifically, an indicator's outer loading on the associated construct should be greater than any of its cross-loading on other constructs (Hair et al., 2017). These results, presented in table 3, indicated that all item loaded on their respective construct and more highly on their respective construct than any other. 
Table 3. Outer loadings and cross-loadings for the indicators of each measurement

\begin{tabular}{|c|c|c|c|c|c|}
\hline Indicator & $\mathrm{BO}$ & TI & JS & WE & WB \\
\hline MBI-1 & .88 & .43 & -.37 & -.22 & .36 \\
\hline MBI-2 & .87 & .39 & -.29 & -.16 & .32 \\
\hline MBI-3 & .87 & .44 & -.36 & -.22 & .34 \\
\hline MBI-4 & .88 & .42 & -.45 & -.24 & .35 \\
\hline MBI-6 & .84 & .41 & -.43 & -.24 & .35 \\
\hline TI-1 & -.20 & .70 & -.17 & -.33 & .21 \\
\hline TI-2 & .26 & .77 & -.27 & -.23 & .22 \\
\hline TI-3 & .45 & $\underline{.83}$ & -.49 & -.33 & .34 \\
\hline TI-4 & .41 & $\underline{.82}$ & -.30 & -.26 & .26 \\
\hline TI-5 & .33 & $\underline{.82}$ & -.30 & -.26 & .26 \\
\hline TI-6 & .45 & $\underline{.85}$ & -.46 & -.31 & .35 \\
\hline TI-7 & .41 & .84 & -.31 & -.25 & .29 \\
\hline JS-1 & -.33 & -.34 & $\underline{.81}$ & .26 & -.24 \\
\hline JS-2 & -.38 & -.42 & $\underline{.88}$ & .34 & -.31 \\
\hline JS-4 & -.40 & -.37 & $\underline{.83}$ & .32 & -.23 \\
\hline WE-Vigor & -.29 & -.33 & .34 & .94 & -.28 \\
\hline $\begin{array}{l}\text { W E E } \\
\text { Absortion }\end{array}$ & -.16 & -.28 & .28 & $\underline{.93}$ & -.20 \\
\hline $\begin{array}{l}\text { W } \quad E \\
\text { Dedication }\end{array}$ & -.23 & -.34 & .39 & .95 & -.27 \\
\hline WB-PB & .36 & .32 & -.28 & -.26 & .97 \\
\hline WB-WRB & .41 & .38 & -.33 & -.28 & $\underline{.98}$ \\
\hline
\end{tabular}

Note: $\mathrm{BO}=$ Burnout, $\mathrm{TI}=$ Turnover Intention, $\mathrm{JS}=\mathrm{Job}$ Satisfaction, WE=Work Engagement, $\mathrm{MBI}=$ Maslach Burnout Inventory, $\mathrm{WB}=$ Workplace Bullying, $\mathrm{PB}=$ Personal Bullying, WRB=Work Related Bullying.
Henseler et al. (2015) propose assessing the heterotrait-monotrait ratio (HTMT) of the correlations to also examine discriminant validity. The HTMT approach is an estimate of what the true correlation between two constructs would be, if they were perfectly measured. A correlation between to constructs close to one indicates a lack of discriminant validity. Therefore, Henseler et al. suggest a threshold value of .90 if the path model includes constructs that are conceptually very similar. In other words, a HTMT above .90 suggest a lack of discriminant validity. Correlations between constructs appear on table 4 , all correlations are below the threshold of .90 , suggesting the discriminant validity of the measures. Also, since the HTMT can serve as the basic of a statistical discriminant validity test. Henseler et al. (2015) recommend the use of bootstrapping technique to derive a bootstrap with a 95\% confidence interval with 5,000 random subsamples. Thus a confidence interval containing the value of one indicates a lack of discriminant validity. Conversely, if the value of one falls outside the interval's range, this suggests that the two constructs are empirically distinct. Since HTMT-based assessment using confidence interval relies on inferential statistics, one should primarily rely on this criterion. In the present study, none of the correlation between the constructs in the bootstrapping 95\% confidence interval included the value of one; therefore, this suggests that the constructs are empirically distinct (see table 4).

Table 4. Heterotrait-Monotrait ratio of correlations (HTMT)

\begin{tabular}{|c|c|c|c|c|c|}
\hline Measure & WB & JS & WE & $\mathrm{BO}$ & $\mathrm{TI}$ \\
\hline \multicolumn{6}{|l|}{ Workplace Bullying (WB) } \\
\hline Job Satisfaction (JS) & $\begin{array}{l}.35 \\
{[.28 ; .42]}\end{array}$ & & & & \\
\hline Work Engagement (WE) & $\begin{array}{l}.29 \\
{[.22 ; .36]}\end{array}$ & $\begin{array}{l}.41 \\
{[.35 ; .48]}\end{array}$ & & & \\
\hline Burnout (BO) & $\begin{array}{l}.42 \\
{[.37 ; .48]}\end{array}$ & $\begin{array}{l}.51 \\
{[.45 ; .57]}\end{array}$ & $\begin{array}{l}.26 \\
{[.20 ; .33]}\end{array}$ & & \\
\hline Turnover Intention (TI) & $\begin{array}{l}.37 \\
{[.32 ; .42]}\end{array}$ & $\begin{array}{l}.51 \\
{[45 ; .56]}\end{array}$ & $\begin{array}{l}.36 \\
{[.30 ; .42]}\end{array}$ & $\begin{array}{l}.51 \\
{[.46 ; .56]}\end{array}$ & \\
\hline
\end{tabular}

Note: Elements in the brackets are the Confident Intervals of .90 of the HTMT's criteria for correlations. 


\section{The structural model}

After the measurements were tested for validity, the structural model as provided in Figure 1, which represent the relations among the constructs assumed in the theoretical model or latent variables, was tested. In order to examine the structural model and as recommended by Hair et al. (2017), first, we checked the structural model for collinearity issues by examining the variance inflation factor (VIF) value of all sets of predictor constructs in the structural model. They fluctuated between 1.000 and 1.548, all VIF values are clearly below the threshold of 5; therefore, collinearity among predictor constructs is not a critical issue in the structural model (see table 5). Also, table 5 shows the $\mathrm{R}^{2}$ values of job satisfaction (.053), work engagement (.075), burnout (.157), and turnover intention (.310), explaining 5.3\%, 7.5\%, $15.7 \%$, and $31.0 \%$ of the variance, respectively. Falk and Miller (1992) suggest a value of .10 for a R-squared as a minimum satisfactory level, only burnout and turnover intention endogenous latent variables reached the threshold level of the R-squared values. Also, the $\mathrm{Q}^{2}$ value which represent an indicator of the model's out-of-sample predictive power or predictive relevance (Hair et al., 2017, p. 202). When PLS path model exhibits predictive relevance, it accurately predicts data not used in the model estimation. In the structural model, Q2 values larger than zero for specific reflective endogenous latent variable indicate the path model's predictive relevance for a particular dependent construct. Thus, all $\mathrm{Q}^{2}$ values of job satisfaction, work engagement, burnout, and turnover intention are above zero $(.033, .061$, $.111, \& .180$, respectively). Providing support of the model's predictive relevance regarding the endogenous latent variables. The effects sizes for workplace bullying achieved $\mathrm{f}^{2}$ values of .06 on job satisfaction, .08 on work engagement, .19 on burnout, and .03 on turnover intention, which reached or exceeds the minimum threshold of .02 (Chin, Marcolin, \& Newsted, 2003). While effect sizes for job satisfaction, work engagement, and burnout achieved the minimum threshold on turnover intention endogenous latent variable.

Table 5. Structural model results

\begin{tabular}{|c|c|c|c|c|c|c|c|c|}
\hline \multirow{2}{*}{ Construct } & \multirow{2}{*}{$\mathrm{R}^{2}$} & \multirow{2}{*}{ Adj. $R^{2}$} & \multicolumn{4}{|l|}{$\mathrm{f}^{2}$} & \multirow{2}{*}{$\mathrm{Q}^{2}$} & \multirow{2}{*}{ VIF } \\
\hline & & & JS & WE & $\mathrm{BO}$ & TI & & \\
\hline Workplace Bullying & & & .06 & .08 & .19 & .03 & & 1.000 \\
\hline Job Satisfaction (JS) & .053 & .052 & & & & .02 & .033 & 1.541 \\
\hline Work Engagement (WE) & .075 & .074 & & & & .02 & .061 & 1.548 \\
\hline Burnout (BO) & .157 & .156 & & & & .15 & .111 & 1.243 \\
\hline Turnover Intention (TI) & .310 & .308 & & & & & .180 & \\
\hline
\end{tabular}

Figure 3 and table 6 show the structural model of results for all direct effects and the beta values of all path coefficients are also shown. Workplace bullying had positive and significant relation to turnover intention $(b=.128, p<.001)$ and burnout $(b=.397, p<.001)$. On the other hand, exposure to workplace bullying had negative and significant relation to job satisfaction $(b=-.311$, $\mathrm{p}<.001)$ and work engagement $(\mathrm{b}=-.273, \mathrm{p}<$ $.001)$. Meanwhile, job satisfaction has negative and significant relation to turnover intention $(b=$ $-.224, \mathrm{p}<.001)$. While work engagement has a negative and significant relation to turnover intention $(b=-.151, p=.001)$. Finally, burnout had a positive and significant relation to turnover intention $(b=.292, p<.001)$. 


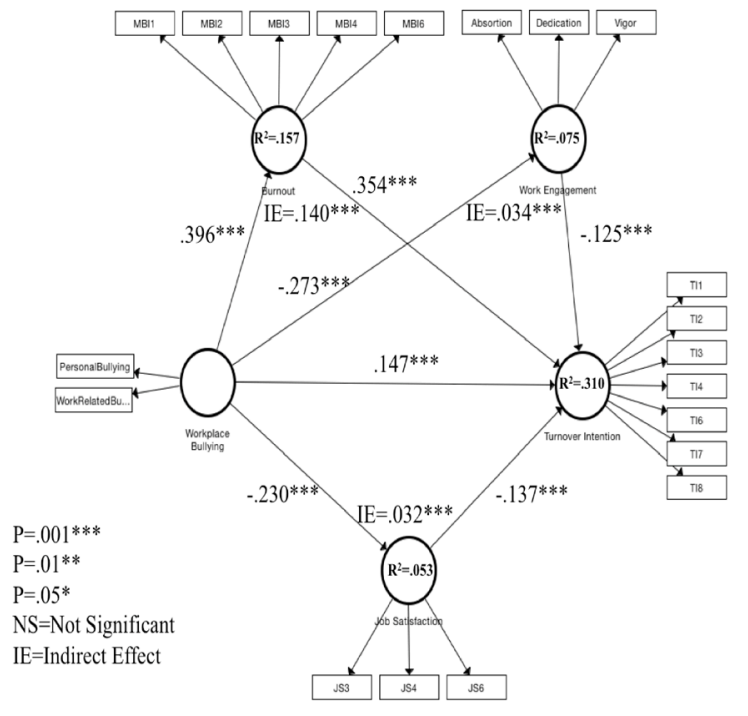

Figure 3: Direct and indirect effect results
In terms of the mediating effects of job satisfaction, work engagement, and burnout, we found that the three mediated the relation between workplace bullying and turnover intention. The total indirect effect was .206 and specific indirect effects of job satisfaction, work engagement, and burnout on turnover intention were all positive and significant as shown in table $7(.032, .034, \&$ .120 , respectively).

\section{Discussion}

The current study aimed to examine the relation between the exposure to workplace bullying and turnover intention and how this relation was mediated by job satisfaction, work engagement, and burnout. Findings concerning turnover intention as another outcome of

Table 6. Direct effect hypotheses, results and conclusions

\begin{tabular}{llll}
\hline & Hypothesis & Results & Conclusion \\
\hline $\mathrm{H}_{1}:$ & Workplace bullying is positively related to turnover intention. & $\mathrm{b}=.147^{* * *}$ & Supported \\
$\mathrm{H}_{2}:$ & Job satisfaction is negatively related to turnover intention. & $\mathrm{b}=-.137^{* * *}$ & Supported \\
$\mathrm{H}_{3}:$ & Work engagement is negatively related to turnover intention. & $\mathrm{b}=-.125^{* * *}$ & Supported \\
$\mathrm{H}_{4}:$ & Burnout is positively related to turnover intention. & $\mathrm{b}=.354^{* * *}$ & Supported \\
$\mathrm{H}_{5}:$ & Workplace bullying is negatively related to job satisfaction. & $\mathrm{b}=-.230^{* * *}$ & Supported \\
$\mathrm{H}_{6}:$ & Workplace bullying is negatively related to work engagement. & $\mathrm{b}=-.273^{* * *}$ & Supported \\
$\mathrm{H}_{7}:$ & Workplace bullying is positively related to burnout. & $\mathrm{b}=.396^{* * *}$ & Supported \\
\hline
\end{tabular}

Note: $\mathrm{n}=1,046 ;{ }^{*} \mathrm{p}<.05,{ }^{* *} \mathrm{p}<.01,{ }^{* * *} \mathrm{p}<.001$.

Table 7. Individual mediation hypotheses result, conclusion, and type of mediation

\begin{tabular}{lllll}
\hline & Hypothesis & Indirect Effect & Conclusion & $\begin{array}{l}\text { Mediation } \\
\text { (Yes / No; Type) }\end{array}$ \\
\hline $\mathrm{H}_{8}: \quad \begin{array}{l}\text { Job satisfaction negatively mediates the relation } \\
\text { between exposure to workplace bullying and turnover } \\
\text { intention. }\end{array}$ & Supported & Yes (Competitive) \\
$\mathrm{H}_{9}: \quad \begin{array}{l}\text { Work engagement negatively mediates the relation } \\
\text { between exposure to workplace bullying and turnover } \\
\text { intention. }\end{array}$ & Supported & Yes (Competitive) \\
$\mathrm{H}_{10}: \quad \begin{array}{l}\text { Burnout positively mediates the relation between } \\
\text { exposure to workplace bullying and turnover } \\
\text { intention. }\end{array}$ & Supported & Yes (Complementary) \\
\hline Note: $\mathrm{n}=1,046 ; * \mathrm{p}<.05, * * \mathrm{p}<.01, * * * \mathrm{p}<.001$. & &
\end{tabular}


exposure to workplace bullying is supported by previous findings (Bahjat et al., 2017; Coetzee \& Oosthuizen, 2017; Coetzee \& van Dyk, 2017; Mathisen, Einarsen, \& Mykletun, 2008; Quine, 1999; Rasool et al., 2013). Current results suggest that the notion of exposure to workplace bullying may be a precursor of exclusion from working life as some of the literature indicates (e.g., Berthelsen et al., 2011). Leymann (1996) argues that organizations need to handle workplace bullying properly because critical and must needed skilled employees who are exposed to such negative acts at work may exit the company as the final stage of the bullying process; in fact, according to Piñuel y Zabala (2001), it is the ultimate goal of the bullied. However, another explanation may be that turnover intention have become a way of coping of such negative acts at work to those employees exposed (Björkquist et al., 1994; Davanport et al., 1999; Namie, 2000; Quine, 1999) because is an escape behavior due to the negative and intrusive nature of the exposure to workplace bullying (Zapf \& Gross, 2001). Furthermore, we concur with Zapf and Gross (2001), who indicate that leaving the organization removes exposed employees from the source of the problem altogether. In terms of the direct effects of job satisfaction, work engagement, and burnout, all had direct effects on turnover intention as found in other studies (e.g., Abu Raddaha et al., 2012; Coetzee \& van Dyk, 2017; Nielsen \& Einarsen, 2012; Xie et al., 2015); nevertheless, all their direct effects were somewhat stronger than exposure to workplace bullying, especially burnout.

Besides that exposure to workplace bullying had a direct effect on turnover intention, it had also a direct and significant effect on job satisfaction, work engagement, and burnout on the direction expected on each one of them. Current results suggest that exposure to workplace bullying has a negative effect on job satisfaction and work engagement; and yet, it has the opposite effect on burnout. In other words, exposure to workplace bullying decrease job satisfaction and work engagement, but exacerbates burnout symptoms, which is consonant with some of the literature about work-related outcomes to the exposure to workplace bullying behaviors (e.g., Nielsen \& Einarsen, 2012; Raja et al., 2017; Rodríguez Muñoz et al., 2009).

Similarly, results from the current study suggest a possible pathway of the exposure to workplace bullying on turnover intention through job satisfaction, work engagement, and burnout. All significantly mediated the relationship between exposure to workplace bullying and turnover intention. However, the biggest indirect effect of exposure to workplace bullying on turnover intention was through burnout. Moreover and according to Zhao, Lynch, and Chen (2010) typology of mediation, job satisfaction and work engagement mediate competitively the relationship between exposure to workplace bullying and turnover intention; in other words, the direct and indirect effect paths are significant and in opposite directions. On the other hand, burnout mediates this relationship in a complementary way; in other words, the direct and indirect effects path are significant and in the same direction. Thus, exposure to workplace bullying may deteriorate mental and physical health of its victims depleting their resources to manage such chronic stressor and for that reason exposed employees consider to leave their organizations in order to stop the exposure of workplace bullying behaviors and the loss of their resources.

\section{Theoretical and practical implications}

The Stress-Strain-Turnover Process model (Fila et al., 2016) appears to explain the results of the current study despite the fact that we only tested it partially because we did not examine actual turnover; instead, we tested turnover intention, which is a precursor of the actual turnover. Nevertheless, including a hindering social stressor such as the exposure to workplace 
bullying, which has a very strong negative impact on strain, expand the theoretical framework. Moreover, results from the current study also support the notion of the model that strain plays a critical role in the decision of an employee to consider leaving the organization.

In terms of practical implications, the current study provides an insight of the harmful effects that exposure to workplace bullying has on turnover intention, job satisfaction, work engagement and burnout. Given the fact that exposure to workplace bullying has detrimental effects at both individual and organizational levels, organizations should response appropriately recognizing the negative implications of bullying at work. For instance, Ferris (2004) suggests that a common organizational response to workplace bullying is acknowledgement that bullying is considered normal in organizational culture and that any resulting harm is due to a lack of personal resilience, personality clash or often deny that the situation is relevant to the business, leaving the parties to settle the conflict. Further, Bentley et al. (2009; cited in Blackwood, Catley, Bentley \& Tapping, 2013) argue that there are misunderstandings about what behaviors constitute workplace bullying due to the fact that they can often be subtle and discrete and the subjective interpretation of the behaviors and the context in which they occur are vital to understanding the harm experienced by the victim. According to Blackwood et al. (2013), these responses are of concern, considering organizations that accept workplace bullying or fail to accept responsibility for bullying in their workplace are not only likely to suffer from organizational costs of an unhealthy work environment, but can also be held legally accountable. Therefore, we echo with Blackwood et al. (2013) that it is imperative that organizations understand the nature of workplace bullying and approaches to prevention and intervention, and the implementation of zero-tolerance policy should also be made a priority in order to create a bullyfree culture and a culture of respect, alongside measure to enforce and embed its legitimacy and authority.

Furthermore, the results of the current study show the indirect effects of the exposure to workplace bullying on turnover intention through strain, especially the mediating effect of burnout in this relationship. Thus, needed components to accompany the zero-tolerance policy are surveillance, organizational support and training (Blackwood et al., 2013). This surveillance and monitoring demonstrates the commitment that the organization has to its zero-tolerance policy; for instance, if a supervisor notice that an employee is, for example, burned out may refer him/her to the Employee Assistance Program to receive support in managing it. Finally, employee and management training provides further opportunities to communicate and reinforce organization's expectations of acceptable and unacceptable behaviors. Also, training would provide details of policy, how to recognize bullying, how to go about reporting incidents of bullying, and how to assist co-workers who are targets of bullying.

Thus, occupational psychologists, managers and human resource professionals have to be aware that changing negative psychosocial aspects of the work environment, such as exposure to workplace bullying could be heightened by drawing the connection between stress, strain, turnover intention and unwanted turnover (Fila et al., 2016). Fila et al. add that the creation of a healthy psychosocial work environment may be extremely important for catching employee strain experiences, negative job attitudes, and even turnover intentions themselves before undesirable turnover occurs.

\section{Limitations and recommendations}

The current study has several shortcomings that must be recognized when interpreting the 
results. First, the fact that we used self-reports to measure all the variables, which may increase the risk of common method variance. However, we conducted a common method variance (CMV) analysis using SPSS and the results shown that CMV was only $26.10 \%$, which is well below the threshold of 50\% (Podsakoff, MacKenzie, Lee, \& Podsakoff, 2003) and this suggest that the use of self-reports was not a problem. Second, the crosssectional design of our study does not allow us to conclude in terms of causal relationships. The use of a longitudinal design will offer more information in terms of the impact of workplace bullying on turnover intention and the final action of leaving the organization in a long-term, the actual turnover incident. As a matter of fact, another limitation of the current study is in itself examining the effects of exposure to workplace bullying on turnover intention instead of examining the effects on actual turnover incidents. This is arguably because gathering data on actual turnover intention can be less problematic than acquiring data of actual turnover incidents (e.g., Avey, Luthans, \& Jensen, 2009; Fila et al., 2016; Schaubroeck, Cotton, \& Jennings, 1989). Moreover, Hom, Mitchell, Lee, and Griffeth (2012) indicate that using turnover intention as a substitute outcome of actual turnover is problematic because only share at most $25 \%$ of the actual turnover variance (Griffeth el al., 2000) and it is inaccurate to assume that employees with weak or no turnover intention strongly desire to stay in the organization (Steel \& Lounsbury, 2009). However, the theory of planned behavior (Ajzen \& Fishbein, 1980) suggests that behavior intention precedes behavior. In this regard, Hom and Kinicki (2001) found in a study of turnover in retail store employees that $60 \%$ of employees who had answered "Definitively Yes" to a question of intention to quit had left the organization six months later. Given the central role of turnover intention on the mechanism in the turnover process (Steel \& Lounsbury, 2009), there is almost general acceptance that turnover is preceded by turnover intention (e.g., Griffeth \& Hom, 2001; Hom \& Griffeth, 1995). Nevertheless, the information obtained from the results of the study gives us an idea of the impact of workplace bullying on turnover intention, especially in a Puerto Rican sample. Thus, giving the high prevalence of workplace bullying in Puerto Rico (WBA, 2015), and its apparent impact on turnover intention, actual turnover incident should be considered in future research to examine fully the Stress-StrainTurnover Process model (Fila et al., 2016), and to better understand mechanisms of exposure to workplace bullying-job attitudes-strains-turnover intention-actual turnover.

\section{Conclusions}

Our results suggest that the exposure to workplace bullying seem to have an effect on turnover intention. Moreover, job satisfaction, work engagement and burnout have a direct effect on turnover intention and these direct effects are stronger that those of the exposure to workplace. Also, they partially mediate the relation between exposure to workplace bullying and turnover intention. Giving the results of the present study, occupational psychologists, managers, and human resource professionals should be aware of the effects of exposure to workplace bullying on employees and how this could result in strain that may lead to turnover intention and the actual turnover incident, which become a way to cope with exposure to workplace bullying for the victims. Therefore, exposure to workplace bullying brings a challenge for psychologists in occupational context, managers, and human resources practitioners in the management of this phenomenon in organizations due to its individuals and organizational costs.

\section{References}

Abbasi, S.M., Hollman, K.W., Hayes, R.D. (2008). Bad bosses and how not to be one. Information Management Journal, 42(1), $52-56$. 
Abu Raddaha, A.H., Alasad, J., Albikawi, Z.F., Batarseh, K.S., Realat, E.A., Saleh, A.A., \& Froelicher, E.S. (2012). Jordanian nurses' job satisfaction and intention to quit. Leadership in Health Services, 25(3), 216-231. doi: $10.1108 / 17511871211247651$

Ajzen, I., \& Fishbein, M. (1980). Understanding attitudes and predicting social behavior. Englewood Cliffs, NJ: Prentice-Hall.

Avey, J.B., Luthans, F., \& Jensen, S.M. (2009) Psychological Capital: A Positive Resource for Combating Employee Stress and Turnover. Human Resource Management, 48, 677-693. doi: 10.1002/hrm.20294

Bagozzi, R.P. \& Edwards, J.R. (1998). A general approach for representing constructs in organizational research. Organizational Research Methods, 1, 45-87. $10.177 / 109442819800100104$

Bahjat, E., Aljawazneh, B., Moh, Z., Smadi, A., \& Ziad, S. (2017). Workplace bullying as a predictor of intention to leave among workers at the industrial organizations in Jordan. International Journal of Academic Research in Economics and Management Sciences, 6(1), 15-39. doi: 10.6007/ IJAREMS/v6-i1/2559

Bakker, A., Demerouti, E., \& Verbeke, W. (2004). Using the Job Demands-Resources Model to predict burnout and performance, Human Resource Management, 43(1), 83104.

doi: 10.1002/hrm.20004

Bakker, A. B., Schaufeli, W. B., Leiter, M. P., \& Taris, T. W. (2008). Work engagement: An emerging concept in occupa- tional health psychology. Work \& Stress, 22(3), 187200.
Barlett, J.E. \& Barlett, M.E. (2011). Workplace bullying: An integrative literature review. Advances in Developving Human Resources, 13(1), 69-84. doi: $10.1177 / 1523422311410651$

Bernstein, C. \& Trimm, L. (2016). The impact of workplace bullying on individual wellbeing: The moderating role of coping. South Africa of Human Resource Management, 14(1), a792. doi: 10.4102/ sajhrm.v14i1.792

Berthelsen, M., Skogstad, A., Lau, B., \& Einarsen, S. (2011). Do they stay or do they go? A longitudinal study of intentions to leave and exclusión from working life among targets of workplace bullying. Journal of Manpower, 32(2), 178-193. doi: $10.1108 / 01437721111130198$

Biggs, A., Brough, P., \& Barbour, J.P. (2014). Enhancing work-related attitudes and work engagement: A quasi-experimental study of the impact of an organizational intervention. International Journal of Stress Management, 21(1), 43-68.

Björkqvist, K., Österman, K., \& Lagerspetz, K.M.J. (1994). Sex differences in covert aggression among adults. Aggressive Behavior, 20(1), 27-33. doi:10.1002/10982337 ( 1994 ) $20: 1 \% 3$ C 27 : : A ID AB2480200105\%3E3.0.CO;2-Q

Blackwood, K., Catley, B., Bentley, T., \& Tappin, D. (2013). Bullying at Work: It's meaning for HRM and Employment Relations. In J. Parker (Ed.), The Big Issues in Employment: HR Management and Employment Relations in New Zealand. Auckland, New Zealand: $\mathrm{CCH}$ New Zealand Limited.

Bowling, N.A., \& Beehr, T.A. (2006). Workplace harassment from the victim's perspective: A theoretical model and meta-analysis. 
Journal of Applied Psychology, 91(5), 998-1012. doi:10.12691/ajap-2-4-3

Brotheridge, C. \& Grandey, A.A. (2002). Emotional labor and burnout: Comparing two perspectives of people work. Journal of Vocational Behavior 60, 17-39. doi:10.1006/jvbe.2001.1815

Carlson, D.S., Kacmar, K.M., Wayne, J.H. and Grzywacz, J.G. (2006). Measuring the positive side of the work-family interface: Development and validation of a workfamily enrichment scale. Journal of Vocational Behavior, 68(1), 131-164.

Cherniss, C. (1980). Staff burnout: Job stress in the human services. London: Sage Publications.

Clausen, T., Hansen, J. V., Hogh, A., Garde, A. H., Persson, R., Conway, P. M., Grynderup, M., Hansen, A. M., \& Rugulies, R. (2016). Exposure to negative acts and risk of turnover: A study of a registerbased outcome among employees in three occupational groups. International Archives of Occupational and Environmental Health, 89(8), 1369- 1278. doi: $10.1007 / \mathrm{s} 00420-016-1161-3$

Chin, W.W. (2010). How to write up and report PLS analyses. In W. Esposito Vinzi, W.W. Chin, J. Henseler, \& H. Wang (Eds.), Handbook of partial least squares: Concepts, methods and applications (pp. 655-690). London: Springer.

Chin, W.W., Marcolin, B.L., \& Newsted, P.R. (2003). A partial least squares latent variable modeling approach for measuring interaction effects: Results from a Monte Carlo simulation study and voice mail emotion/adoption study. Information System Research, 14, 189-217.
Coetzee, M. \& Oosthuizen, R.M. (2017). Workrole psychosocial flourishing: Its mediation role on workplace bullying and employee turnover intention. Journal of Psychology in Africa. 27(3), 211-215. doi: 10.1080/14330237.2017.1321826

Coetzee, M. \& van Dyk, J. (2017). Workplace bullying and turnover intention: Exploring work engagement as a potential mediator. Psychological Reports, 121(2), 375-392. doi: $10.1177 / 0033294117725073$

Davenport, N., Schwartz, R.D. \& Elliott, G.P. (1999) Mobbing: Emotional Abuse in the American Workplace. Ames, IA: Civil Society Publishing.

Demerouti, E., Bakker, A.B., \& Bulters, A.J. (2004). The loss spiral of work pressure, work-home interference and exhaustion: Reciprocal relations in a three-wave study. Journal of Vocational Behavior, 64(1), 131-149. doi: 10.1016/S00018791(03)00030-7

Demerouti, E., Bakker, A.B., Vardakou, L., \& Kantas, A. (2003). The convergent validity of two burnout instruments: A multitraitmultimethod analysis. European Journal of Psychological Assessment, 18, 296307. doi: 10.1027//1015-5759.19.1.12

De Tienne, K., Agle, B., Phillips, J., \& Ingerson, M.C. (2012). The impact of moral stress compared to other stressors on employee fatigue, job satisfaction, and turnover: An empirical investigation. Journal of Business Ethics, 110(3), 377-391. doi: 10.1007/s10551-011-1197-y

Egan, T.M., Yang, B. \& Bartlett, K.R. (2004). The effects of organizational learning culture and job satisfaction on motivation to transfer learning and turnover intention. Human Resource Development Quarterly, 15(3), 279-301. 
Einarsen, S., Raknes, B.J., \& Matthiesen, S.B. (1994). Bullying and harassment at work and their relationships to work environment quality: An exploratory study. European Work and Organizational Psychologist, 4(4), 381-401. doi: $10.1080 / 13594329408410497$

Einarsen, S., Hoel, H., Zapf, D., \& Cooper, C.L. (2011). The concept of bullying and harassment at work: The European tradition. In S. Einarsen, H. Hoel, D. Zapf, \& C.Cooper (Eds.), Bullying and harrassment in the workplace: Developments in theory, research, and practice (pp.3-40). London: CRC Press.

Einarsen, S, Matthiesen, SB and Skogstad, A. (1998). Bullying, burnout and wellbeing among assistant nurses. Journal of Occupational Health and Safety-Australia and New Zealand, 14, 263-268.

Falk, R.F. \& Miller, N.B. (1992). A primer for soft modeling. Akron, $\mathrm{OH}$ : The University of Akron Press.

Ferris, P. (2004). A preliminary typology of organizational response to allegations of workplace bullying: See no evil, hear no evil, speak no evil. British Journal of Guidance \& Counseling, 32(3), 389-395. doi: 10.1080/03069880410001723576

Fila, M.J. (2014). Stressful work and turnover: The mediating role of psychological strain. Presented at the 74th Annual Meeting of the Academy of Management, Philadelphia, Pennsylvania.

Fila, M.J., Eatough, E., \& Griffeth, R.W. (2016). Stressful work and voluntary turnover. In A.M. Rossi, J.M. Meurs, \& P.L. Perrewé (Eds.), Stress and quality of working life: Interpersonal and occupation-based stress (pp.147-164). Charlotte, NC: Information Age Publishing.
Fornell, C. \& Larcker, D.F. (1981). Evaluating structural equation models with unobservable variables and measurement Error. Journal of Marketing Research, 18(1), 39-50. doi:10.2307/3151312

Häusser, J.A., Mojzisch, A., Niesel, M., \& SchulzHardt, S. (2010). Ten years on: A review of recent research on the Job Demand-Control (-Support) model and psychological wellbeing. Work \& Stress, 24(1), 1-35. doi: $10.1080 / 02678371003683747$

Glambek, M., Matthiesen, S.B., Hetland, J., \& Einarsen, S. (2014). Workplace bullying as an antecedent to job insecurity and intention to leave: a 6-month prospective study. Human Resource Management Journal, 24(3), 255-268. doi: $10.1111 / 1748-8583.12035$

González-Romá, V., Schaufeli, W.B., Bakker, A.B., \& Lloret, S. (2006). Burnout and work engagement: Independent factors or opposite poles? Journal of Vocational Behavior, 68(1), 165-174. doi: 10.1016/j. jvb.2005.01.003

Griffeth, R.W. \& Hom, P.W. (2001). Retaining valued employees. Thousand Oaks, CA: SAGE Publications.

Griffeth R. W., Hom P. W., Gaertner S. (2000). A meta-analysis of antecedents and correlates of employee turnover: Update, moderator tests, and research implications for the millennium. Journal of Management, 26(3), 463-488.

Hair, J.F., Hult, G.T.M., Ringle, C.M., \& Sarstedt, M. (2017). A primer on partial least squares structural equation modeling (PLS-SEM). Los Angeles: SAGE Publications.

Hall, R.J., Snell, A.F., \& Foust, M. (1999). Item parceling strategies in SEM: Investigating the subtle effects of unmodel 
secondary constructs. Organizational Research Methods, 2, 233-256. doi: $10.1177 / 109442819923002$

Happell, B., Martin, T., \& Pinikahana, J. (2003). Burnout and job satisfaction: A comparative study of psychiatric nurses from forensic and a mainstream mental health service. International Journal of Mental Health Nursing, 12(1), 39-47. doi: 10.1046/j.1440-0979.2003.00267.x

Hauge, L.J., Skogstad, A., \& Einarsen, S. (2010). The relative impact of workplace bullying as a social stressor at work. Scandinavian Journal of Psychology, 51(5), 426-433. doi: $10.1111 /$ j.1467-9450.2010.00813.x.

Henseler, J., Ringle, C.M., \& Sarstedt, M. (2015). A new criterion for assessing discriminant validity in variance-based structural equation modeling. Journal of the Academy of Marketing Science, 43, 115-135.

Hobfoll, S.E. (1989). Conservation of resources: A new attempt at conceptualizing stress. The American Psychologist, 44(3), 513524.

Hobfoll, S. E., \& Shirom, A. (2001). Conservation of resources theory: Applications to stress and management in the workplace. In R. T. Golembiewski (Ed.), Handbook of organizational behavior (pp. 57-80). New York, NY: Marcel Dekker.

Hoel, H., Sheehan, M., Cooper, C. and Einarsen, S. (2011). Organisational effects of workplace bullying. In S. Einarsen, $\mathrm{H}$. Hoel, D. Zapf and C.L. Cooper (Eds.), Bullying and harassment in the workplace: Developments in theory, research, and practice (pp. 129-147). London, UK: Taylor \& Francis.
Hom P. W. \& Griffeth R. (1995). Employee Turnover. Cincinnati, OH: South Western Publishing.

HomP.W. \& Kinicki, A.J. (2001). Toward a greater understanding of how dissatisfaction drives employe turnover. Academy of Management Journal, 4(5), 975-987.

Hom, P.W., Mitchell, T.R., Lee, T.W., \& Griffeth, R.W. (2012). Reviewing employee turnover: Focusing on proximal withdrawal states and expanded criterion. Psychological Bulletin, 138(5), 831-858. doi: $10.1037 / \mathrm{a} 0027983$

Irvine, D.M. \& Evans, M.G. (1995). Job satisfaction and turnover among nurses: Integrating research findings across studies. Nursing Research, 44(4), 246253.

Jourdain, G., \& Chênevert, D. (2010). Job demands-resources, burnout and intention to leave the nursing profession: A questionnaire survey. International Journal of Nursing Studies, 47, 709-722.

Judge, T. A., Hulin, C. L., \& Dalal, R. S. (2012). Job satisfaction and job affect. In S.W. J. Kozlowski (Ed.), The Oxford Handbook of Industrial and Organizational Psychology (pp.496-525). Oxford, UK: Oxford University Press.

Kahn, R. L., \& Byosiere, P. (1992). Stress in organizations. In M. D. Dunnette \& L. M. Hough (Eds.), Handbook of industrial and organizational psychology (pp. 571650). Palo Alto, CA, US: Consulting Psychologists Press.

Karasek, R. A., \& Theorell, T. (1990). Healthy work: stress, productivity and the reconstruction of working life. New York: Basic Books. 
Laschinger, H.K. \& Finegan, J. (2005). Using empowerment to build trust and respect in the workplace: A strategy for addressing the nursing shortage. Nursing Economics, 23(1), 6-13. doi: $10.1111 / \mathrm{j} .1365-$ 2648.2010.05420.x

Laschinger, H.K.S., Grau, A.L., Finegan, J. \& Wilk, P. (2010) New graduate nurses' experiences of bullying and burnout in hospital settings. Journal of Advanced Nursing, 66(12), 2732-2742.

Lazarus, R. S., \& Folkman, S. (1984). Stress, appraisal, and coping. New York: Springer.

Lee, R.T. \& Ashforth, B.E. (1996). A meta-analytic examination of the correlates of the three dimensions of job burnout. Journal of Applied Psychology, 81(2), 123-133. Ddoi: 10.1037//0021-9010.81.2.123

Leiter, M.P. \& Maslach, C. (2004). Areas of worklife: A structured approach to organizational predictors of job burnout. Emotional and Physiological Processes and Positive Strategies Research in Occupational Stress and Well Being, 3, 91134. doi:10.1016/S1479-3555(03)030038

Leymann, H. (1990). Mobbing and psychological terror at workplaces. Violence and Victims, 5(2), 119-126.

Leymann, H. (1996). The content and development of mobbing at work. European Journal of Work and Organizational Psychology, 5(2), 165184. doi:10.1080/13594329608414853

Little, T.D., Cunningham, W.A., Shahar, G., \& Widaman, K.F. (2002). To parcel or not to parcel: Exploring the question, weighing, the merits. Structural Equation Modeling, 9, 151-173. doi: 10.1207/ S15328007SEM0902_1
Livne, Y. \& Goussinsky, R. (2017). Workplace bullying and burnout among healthcare employees: The moderating effect of control-related resources. Nursing \& Health Sciences, 20(1), 89-98. doi: $10.1111 /$ nha12392

Maslach, C. (1982). Burnout: The cost of caring. Englewood Cliffs, NJ: Prentice-Hall.

Maslach, C. (2004). Different perspectives on job burnout. Contemporary Psychology, 49(2), 168-170. doi: 10.1037/004284

Maslach, C., Jackson, S. E., \& Leiter, M. P. (1996). Maslach Burnout Inventory Manual (3rd ed.). Mountain View, CA: CPP, Inc.

Maslach, C., \& Leiter, M. P. (1997). The truth about burnout: How organizations cause personal stress and what to do about It. San Francisco, CA: Jossey-Bass.

Maslach, C., Schaufeli, W.B., \& Leiter, M.P. (2001). Job burnout. Annual Review of Psychology, 52, 397-422. doi: 10.1146/ annurev.psych.52.1.397

Mathisen, G. E., Einarsen, S., \& Mykletun, R. (2008). The occurrences and correlates of bullying and harassment in the restaurant sector. Scandinavian Journal of Psychology, 49(1), 59-68. doi: 10.1111/j.1467-9450.2007.00602.x

May, D.R., Gilson, R.L., \& Harter, L.M. (2004). The psychological conditions of meaningfulness, safety and availability and the engagement of the human spirit at work. Journal of Occupational and Organizational Psychology, 77(1), 11-37. doi:10.1348/096317904322915892

Meliá, J. L., \& Becerril, M. (2007). Psychosocial sources of stress and burnout in the construction sector: A structural equation model. Psicothema, 19(4), 679-686. 
Mobley, W.H. (1982). Employee turnover: Causes, consequences, and control. Reading, MA: Addison-Wesley.

Moreno Jiménez, B., Rodríguez Muñoz, A., Martínez Gamarra, M., \& Gálvez Herrer, M. (2007). Assessing workplace bullying: Spanish validation of a reduced version of the Negative Acts Questionnaire. The Spanish Journal of Psychology, 10(2), 449-457.

Muchinsky, P. M. \& Culbertson, S.S. (2016). Psychology applied to work. Summerfield, NC: Hypergraphic Press.

Namie, G. (2000). U.S. hostile workplace survey. Retrieved from: http:/www. workplacebullying.org/multi/pdf/ N-N-2000.pdf

Nielsen, M.B. \& Einarsen, S. (2012). Outcomes of exposure to workplace bullying: A meta-analytic review. Work \& Stress: An International Journal of Work, Health \& Organisations, 26(4), 309-332. doi:10.108 $0 / 02678373.2012 .734709$

Nwobia, I.E. \& Aljohani, M.S. (2017). The effect of job dissatisfaction and workplace bullying on turnover intention: Organization climate and group cohesion as moderators. International Journal of Marketing Studies, 9(3), 136-143.

Piñuel y Zabala, I. (2001). Mobbing: Como sobrevivir al acoso psicológico en el trabajo. España: Editorial Sal Terrae.

Podsakoff, P.M., MacKenzie, S.B., Lee, J.Y., \& Podsakoff, N.P. (2003). Common method biases in behavioral research: a critical review of the literature and recommended remedies. Journal of Applied Psychology 88(5), 879-903. doi:10.1037/00219010.88.5.879
Quine, L. (1999). Workplace bullying in NHS community trust: Staff questionnaire survey. British Medical Journal, 318, 228232. doi: $10.1136 / \mathrm{bmj} .318 .7178 .228$

Raja, U., Javed, Y., \& Abbas, M. (2017). A Time Lagged Study of Burnout as a Mediator in the Relationship Between Workplace Bullying and Work-Family Conflict. International Journal of Stress Management. Advance online publication. http://dx.doi.org/10.1037/str0000080

Rasool, F., Arzu, F., Hassan, A., Rafi, A., \& Kashif, A.R. (2013). Workplace bullying and intention to leave: The moderating effect of the organizational commitment. Information Management and Business Review, 5(4), 175-180.

Razzaghian, M. \& Ghani, U. (2014). Effect of Workplace Bullying on Turnover Intention of Faculty Members: A Case of Private Sector Universities of Khyber Pakhtunkhwa, Pakistan. Business \& Economic Review, 6(1), 40-51. doi: $10.22547 / \mathrm{BER} / 6.1 .2$

Ringle, C.M., Wende, S., \& Becker, J-M. (2015). SmartPLS (3.0). Bönningstedt: SmartPLS. Retrieved from http:/www.smartpls.com

Rodríguez-Muñoz, A., Baillien, E., De Witte, H., Moreno-Jiménez, B., \& Pastor, J.C.(2009). Cross-lagged relationships between workplace bullying, job satisfaction, and engagement: Two longitudinal studies. Work \& Stress: An International Journal of Work, Health \& Organizations, 23(3), 225243. doi: $10.1080 / 02678370903227357$

Rodríguez Montalbán, R., Martínez Lugo, M.E. \& Andújar Rojas, C.A. (2011). Análisis de las propiedades de la Escala de Engagement en el Trabajo de Utrecht en un grupo de empleados/as en Puerto Rico. Ponencia presentada en el 1er Congreso 
de Psicología Industrial Organizacional de Puerto Rico:"Acciones Estratégicas para la Gestión del Capital Humano", 1719 marzo de 2011, Ponce Hilton Hotel and Casino, Ponce, Puerto Rico.

Rodwell, J., Brunetto, Y., Demir, D., Shacklock, K., \& Farr-Wharton, R. (2014). Abusive supervision and links to nurse intention to quit. Journal of Nursing Scholarship, 46(5), 357-365. doi: 10.1111/jnu.12089

Rosado Vázquez, J. (2005). Las diferentes estrategias de acoso psicológico y sus efectos en los niveles de depresión en una muestra de empleados públicos. (Unpublished doctoral dissertation). Ponce School of Medicine, Ponce, Puerto Rico.

Rosario-Hernández, E. \& Rovira Millán, L.V. (2011). Estudio empírico de las consecuencias psicológicas del mobbing en una muestra de empleados en Puerto Rico. Revista Interamericana de Psicología Ocupacional, 30(2), 183-199.

Rosario-Hernández, E. \& Rovira Millán, L.V. (2018). Development and validation of the Turnover Intention Scale and the Job Satisfaction Scale. Unpublished manuscript.

Rosario-Hernández, E., Rovira Millán, L.V., Pons Madera, J.I., Rodríguez, M., \& Cordero, A. (2009). El acoso psicológico en el ambiente laboral y el trastorno de estrés postraumático. Revista Interamericana de Psicología Ocupacional, 28(2), 138-148.

Rosario-Hernández, E., Rovira Millán, L.V., Rodríguez Irizarry, A., Velázquez Lugo, A., Rosario Nieves, I. \& Zapata Solá, A. (2013). La relación entre la manifestación de conductas laborales contraproducentes, estresores laborales, emociones y acoso psicológico: El efecto moderador de las emociones negativas. Revista Interamericana de Psicología Ocupacional, 32 (1), 31-52.

Rosario-Hernández, E., Rovira Millán, L.V., Rodríguez Irizarry, A., Rivera Alicea, B.E., Fernández López, L.N., López Miranda, R.S., Segarra Colondres, C., Torres Hernández, J.A., Burgos González, M.Z., González Echevarría, A., Ortiz Blanco, M.A., Padilla Santiago, M.A. \& Torres García. (2014). La salud cardiovascular y su relación con los factores de riesgo psicosociales en una muestra de personas empleadas en Puerto Rico. Revista Puertorriqueña de Psicología, 25(1), 98116.

Rosario-Hernández, E., Rovira Millán, L.V., Comas Nazario, A.R., Medina Hernández, A., Colón Jiménez, R., Feliciano Rivera, Y., Rodríguez Caraballo, B., Hernández Fernández, M., Martínez Julio, F., Díaz Montijo, C., Cabán Valentín, L., Ruíz Pacheco, S., Feliciano Toro, B.P., Marrero Díaz, C., \& Berrios Quiñones, G. (2018). Workplace bullying and its effect on sleep well-being: The mediating role of rumination. Puerto Rican Journal of Psychology, 29(1), 164-186.

Ryan, R.M. \& Deci, E.L. (2001). On happiness and human potentials: A review of research on hedonic and eudaimonic wellbeing. Annual Review of Psychology, 52, 141-166. doi: 10.1146/annurev. psych.52.1.141

Sá, L., \& Fleming, M. (2008). Bullying, burnout, and mental health amongst Portuguese nurses. Issues in Mental Health Nursing, 29(4), 411-426. doi: $10.1080 / 01612840801904480$

Saks, A.M. (2006). Antecedents and consequences of employee engagement. Journal of 
Managerial Psychology, 21(7), 600-619. doi: 10.1108/02683940610690169

Schaufeli, W. B., \& Bakker, A. B. (2004). Job demands, job resources, and their relationship with burnout and engagement: A multi-sample study. Journal of organizational Behavior, 25(3), 293-315.

Schaufeli, W.B., \& Salanova, M. (2007). Work engagement: An emerging psychological concept and its implications for organizations. In S.W. Gilliland, D.D. Steiner, \& D.P. Skarlicki (Eds), Research in social issues in management (Volume 5): Managing social and ethical issues in organizations (pp. 135-177). Greenwich, CT: Information Age Publishers.

Schaufeli, W.B., Salanova. M., GonzálezRomá, V., \& Bakker, A.B. (2002). The measurement of engagement and burnout: A confirmative analytic approach. Journal of Happiness Studies, 3, 71-92.

Schaubroeck, J., Cotton, J.L., \& Jennings, K.R. (1989). Antecedents and consequences of role stress: A covariance structure analysis. Journal of Organizational Behavior, 10(1), 35-58. doi: 10.1002/job.4030100104

Sinha, C. \& Sinha, R. (2012). Factors affecting employee retention: A comparative analysis of two organizations from heavy engineering. European Journal of Business and Managament, 4(3), 145-162.

Steel, R. P., \& Lounsbury, J. W. (2009). Turnover process models: Review and synthesis of a conceptual literature. Human Resource Management Review, 19(4), 271-282. doi: 10.1016/j.hrmr.2009.04.002

Storm, K., \& Rothmann, S. (2003). The relationship between burnout, personality traits and coping strategies in a corporate pharmaceutical group. South Africa
Journal of Industrial Psychology, 29(4), 35-42.

Tett, R.P. \& Meyer, J.P. (1993). Job satisfaction, organizational commitment, turnover intention, and turnover: Path analysis based on meta-analytic findings. Personnel Psychology, 46(2), 259-293. doi: 10.1111/ j.1744-6570.1993.tb00874.x

Timms, C. \& Brough, P. (2013). I like being a teacher: Career satisfaction, the work environment and work engagement. Journal of Educational Administration, 51(6), 768-789. doi: 10.1108/JEA-062012-0072

Todd, C.M. \& Deery-Scmitt, D.M. (1996). Factors affecting turnover among family child care providers: A longitudinal study. Early Childhood Research Quarterly, 11(3), 351-376. doi: $10.1016 / \mathrm{S} 0885$ 2006(96)90012-5

Trevor, C. (2001). Interactions among actual ease-of-movement determinants and job satisfaction in prediction of voluntary turnover. Academy of Management Journal, 44 (6), 621-638. doi: $10.5465 / 3069407$

Warr, P., \& Inceoglu, I. (2012). Job engagement, job satisfaction and contrasting associations with person-job fit. Journal of Occupational Health Psychology, 17(2), 129-138.

Wöck, A. \& Heymann, M. (2012). Impact of demographic variables on voluntary labour turnover in South Africa. The International Journal of Human Resource Management, 23(16), 3479-3494. doi: $10.1080 / 09585192.2011 .639028$

Workplace Bullying Alliance. (May, 2015). 1st National Education Survey about workplace bullying in Puerto Rico. 
Conference presented at the "2nd Educational Discussion on Workplace Bullying", Turabo University, Gurabo, Puerto Rico.

Workplace Bullying Institute (2014). US workplace bullying survey. Retrieved from: http://workplacebullying.org/multi/ pdf/WBI-2014-US-Survey.pdf

Wright, T.A. \& Cropanzo, R. (1998). Emotional exhaustion as a predictor of job performance and voluntary turnover. Journal of Applied Psychology, 83(3), 486-493. doi: $10.1037 / 0021$ 9010.83 .3 .486

Varhama, L.M. \& Björkqvist, K. (2004). Conflicts, workplace bullying and burnout problems among municipal employees. Psychological Reports, 94, 1116-1124.

Van der Doef, M. \& Maes, S. (1999) The Job Demand-Control (- Support) Model and psychological well-being: A review of 20 years of empirical research. Work \& Stress: An International Journal of Work, Health \& Organisations, 13(2), 87-114, doi: $10.1080 / 026783799296084$

van Dyk, J. (2016). The mediating effect of a psychological wellbeing profile in the bullying and turnover intention relation. Unpublished doctoral thesis, University of South Africa, Pretoria, South Africa. Retrieved from: http://uir.unisa.ac.za/bitstream / handle/10500/22265/thesis_van_dyk_j. pdf? sequence $=1 \&$ isAllowed $=\mathrm{y}$
Van Schalkwyk, L.M., Els, C., \& Rothmann, I. (2011). The moderating role of perceived organizational support in the relationship between workplace bullying and turnover intention across sectors in South Africa. South Africa Journal of Human Resource Management, 9(1), a384, 13 pages. doi: https://doi.org/10.4102/sajhrm.v9i1.384

Xie, X. Liu, H., \& Deng, H. (2015). Psychological contract breach and turnover intention: The intermediary role of job satisfaction. Open Journal of Business and Management, 3, 371-379. doi: 10.4236/ojbm.2015.34036

Yeun, Y.R. (2015). A research of workplace bullying and burnout on turnover intention in hospital nurses. Journal of the Korean Academia-Industrial Coorperation Society, 16(12), 8343-8349. doi: 10.5762/ KAIS.2015.16.12.8343

Zapf, D. \& Gross, C. (2011). Conflict escalation and coping with workplace bullying: A replication and extension. European Journal of Work and Organizational Psychology, 10(4), 497-522. doi: $10.1080 / 13594320143000834$

Zapf, D., Seifert, C., Schmutte, B., Mertini, H., \& Holz, M. (2001). Emotion work and job stressors and their effects on burnout. Psychology \& Health, 16(5), 527-545. doi: 10.1080/08870440108405525.

Zhao, X., Lynch, J.G., \& Chen, Q. (2010). Reconsidering Baron and Kenny: Myths and truths about mediation analysis. Journal of Consumer Research, 37, 197206. doi:10.1086/651257 